\title{
Indigenous Legal Resurgence as a Path to Reconciliation: Three Case Studies
}

\author{
Frederico Oliveira' \\ 'Lakehead University, Department of Anthropology, Ontario, Canada
}

\begin{abstract}
The court system has been instrumental lately in dramatically enhancing the opportunity for recognizing Indigenous rights. However, the court system's approach toward the Indigenous limits their autonomy and capacity to establish sovereignty on their own terms. Additionally, the Crown has consistently been reluctant to implement court decisions favourable to native communities and open nation-to-nation dialogues. One of the ways Indigenous nations in Canada are finding to reach a meaningful way to reconciliation is to take an active stand to honour historical agreements and court rulings rather than waiting for the Crown to manifest a genuine disposition to mend the wrongdoings of the past. This paper presents and discusses three recent cases in the legal history of Canada that exemplify a revitalized movement in the affirmation of Indigenous rights, considering several societal aspects that have changed through colonization and, at the same time, asserting the connection with crucial practices in their cultures.
\end{abstract}

Key words: reconciliation, Indigenous resurgence, justice system. 


\section{Ressurgimento Legal Indígena como um Caminho para a Reconciliação: Três Estudos de Caso}

\section{Resumo}

O sistema judiciário tem sido fundamental recentemente para aumentar drasticamente a oportunidade de reconhecimento dos direitos indígenas. No entanto, a abordagem do sistema judiciário em relação aos indígenas serve para limitar sua autonomia e capacidade de estabelecer soberania em seus próprios termos. Além disso, a Coroa tem sido consistentemente relutante em implementar decisões judiciais favoráveis às comunidades nativas e abrir diálogos de nação para nação. Uma das maneiras pelas quais as nações indígenas do Canadá estão encontrando para chegar a uma forma significativa de reconciliação é assumir uma posição ativa para honrar acordos históricos e decisões judiciais, em vez de esperar que a Coroa manifeste uma disposição genuína para consertar os erros do passado. Este artigo apresenta e discute três casos recentes na história jurídica do Canadá que exemplificam um movimento revitalizado na afirmação dos direitos indígenas, considerando diversos aspectos sociais que se modificaram com a colonização e, ao mesmo tempo, afirmando a conexão com práticas importantes em sua culturas.

Palavras-chave: reconciliação, ressurgimento indígena, sistemas de justiça. 


\title{
Indigenous Legal Resurgence as a Path to Reconciliation: Three Case Studies
}

\author{
Frederico Oliveira
}

\section{Introduction}

Reconciliation is a term frequently used by both Canadian government agencies and Indigenous peoples to refer to the process in which a general societal healing takes place, refreshing and mending the relationship between indigenous and settler Canadians (Johnson, 2007; Simpson, 2017). According to the Truth and Reconciliation Commission of Canada (TRC), recognizing Indigenous justice systems and legal traditions is one of the fundamental principles to the path of a meaningful reconciliation process. However, there is also a concern that the initiatives proposed by the Crown, in all its jurisdictions, resonate as empty and nongenuine acts and will thus reproduce the same mistakes that have historically guided the relationships between European and Indigenous nations.

This paper examines three events in the recent history of Aboriginal rights in Canada to discuss how they are in line with a revitalized and active direction to assert the rights to self-government, nation-to-nation relationship, and honour historical agreements as significant means to achieve a righteous path to reconciliation. Indigenous traditions and beliefs have been violently altered and eradicated through colonization; however, the elements of Indigenous traditions that survived are being further spread and re-taught as we work towards decolonization and reconciliation. In the Indigenous holistic worldview whereby the Earth, people, and spirits are all connected, the concept of land ownership does not exist. Consequently, colonial terminologies such as "ceding" or "surrendering" were unrecognizable concepts because they did not exist in the Indigenous language nor consciousness. Furthermore, this holistic philosophy supported ideals of sharing and partnership, all of which were crucial to how Indigenous signatories perceived the intentions of treaties, even though the European signatories did not share their sentiments.

Canadian laws constrict and restrict genuine Aboriginal autonomy by failing to recognize Aboriginal self-government and imposing judicial constraints on Aboriginal laws and rights. (Bell and Asch, 2002). This can be seen, for example, in the notion of stare decisis, which allows decisions to be made uniformly through obligations of treating current cases similar to ones in the past (Bell and Asch, 2002). This means that lower courts decisions should reflect similar or alike outcomes previously established in higher court cases. (:39). However, the doctrine is difficult to apply to discussions of Aboriginal affairs because of various understandings of what the term 'similar' or 'alike' mean (:40). Additionally, the Colonial system inherently works against Indigenous people as demonstrated by the lack of judicial objectivity toward the Indigenous as well as the prohibitive costs associated with court cases. Colonial law is perceived to be fair and objective and, thus in large, desirable to non-Aboriginal Canadians because of its predictability and its subjectivity being controlled by a judge (Bell and Asch, 2002). However, Canadian law does not harmonize well with established Aboriginal self-government and Indigenous law because of the cultural framework in which it is rooted. For example, "Aboriginal rights [that] are pursued originate in European theory and law" and are consequently treated as a collective rather than as an individual (LaRocque, 2002: 78). Warry likewise indicates that "First Nations are different in jurisdiction, government relations, and culture," which further suggests that Colonial law is neither a fair nor beneficial legal system to which the Indigenous should be bound (2007:48). 
More recently, in Canadian courts, the legal nature of Aboriginal title has been considered Sui generis ${ }^{1}$, or unique right, which, in theory, allows courts "to explore beyond the confines of English property law to determine the scope and content of Aboriginal title and its relationship with the Crown's interest" (Bell \& Asch, 2002: 48). Bell and Asch suggest that this idea may allow for a fuller appreciation of "the restraints imposed by the language and concepts of English and Canadian common law" than the previous precedents, which were/are frequently based upon "culture that are both incorrect and highly prejudicial to the Aboriginal party" (Bell \& Asch, 2002: 74). However, Bell and Asch warn that there has been a tradition in Canadian and Crown legal systems to "[mould] Aboriginal interests into familiar categories of English law and measure their enforceability by English standards” (2002: 50).

Leanne Simpson defines reconciliation as the act of restoring harmony; rather than dwelling on the tattered past for the grievances it provides, we may be better suited to forge a better future (2017: 21-22). She points out a need to revitalize native culture and native ways of life by reaffirming the culture, practices and traditions that have lost their values today through constant marginalization. The three examples presented and discussed in this article seek to examine the resurgence of Indigenous cultures. Each of the case studies illustrates how communities and even some levels of the courts find ways to exert influence on other nations to take the lead towards achieving reconciliation. They show that many cultural aspects have changed since colonization, but also that the fundamentals of the native culture are very much alive. The cases illustrate that the renaissance of those fundamentals is more important than ever, despite the continuing obstructions from the colonial legal system and the non-Indigenous populations.

\section{Wet'suwet'en and the natural gas pipeline}

On January 7, 2019, the Royal Canadian Mounted Police entered the Gidumt'en checkpoint established on Wet'suwet'en traditional territory about 300 kilometres west of Prince George in the province of British Columbia. The Gidumt'en checkpoint is the primary access to the Unist'ot'en Camp that connects into the Wet'suwet'en traditional lands. The road is the only entrance for workers to build the Coastal GasLink pipeline through that region. The Wet'suwet'en have formed at least three camps along the road, including the Unist'ot'en healing village that originated as a Wet'suwet'en-operated checkpoint on the road in 2009, not allowing people working on the pipeline to enter the area.

In December 2018, an interim court injunction was granted to Coastal GasLink, ordering clearance of the checkpoint and people to stop preventing company workers from gaining access to the road and bridge. The RCMP came to dismantle checkpoints along the road and enforce the injunction at the Gidimt'em camp on January 2019. Indigenous people protesting against the construction of the pipeline were forcefully removed, and 14 individuals were arrested. The arrests by the RCMP in Wet'suwet'en territory have generated a number of demonstrations and acts of solidarity from other Indigenous nations and supporters around the country. For instance, the Tyendinaga Mohawk Nation members organized a public protest near railway tracks east of Belleville, Ontario, to stop traffic along an important CNR line that led to a shutdown of passenger and freight transportation through eastern Ontario.

At the centre of the dispute is the largest private sector investment in Canadian history with an estimated cost of $\$ 6.6$ billion, a key component of a \$40-billion LNG Canada industrial energy and export terminal. The 670 kilometre-long pipeline would extend from the Dawson Creek area in northeastern B.C. to Kitimat, B.C. There, the conversion from natural gas to liquid form would take place and then the products would be transported to Asian countries. Representatives from Coastal GasLink pipeline affirm the company

1 A relevant case of reference is the Guerin decision (1984). 
has received approval from the province, and 20 First Nations band councils have signed agreements approving the project, including five of the six band councils in the Wet'suwet'en nation. However, the Hereditary Chiefs assert that band councils' authority derives from the Indian Act and their decisions are only restricted to the territory within their individual reserves. The Hereditary Chiefs, as the land protectors and ancestral leaders of the system of governance, have declared that no pipelines or other economic development projects can be developed through their territory without the consent of the clans. They have recognized authority to make decisions over the 22,000 square kilometres on their traditional territory, a portion of land recognized by the Supreme Court of Canada in a 1997 decision as unceded territory.

\section{Discussion}

The conflict over a natural gas pipeline in northern British Columbia is one more recent event involving the natural resource extraction industry and Indigenous rights in a province where large tracts of territory are not covered by any treaty. After receiving extensive evidence, the Supreme Court Delgamuukw decision in 1997 recognized the existence of an organized system governed by the Hereditary Chiefs that predates colonization and continues to exist until today. The system of elected Chief and Council is a legacy of the $19^{\text {th }}$ century Indian Act, a piece of legislation imposed by the federal government to move forward with a nationwide plan to deconstruct native systems of governance, homogenize the relations with Indigenous nations, and prepare the foundation to eventually assimilate them to the mainstream Canadian society.

Law specialists constantly refer to Delgamuukw as a landmark decision to understand the title to the land in Wet'suwet'en territories and other communities under similar circumstances. Even though the court refused to issue a statement in favour of the Wet'suwet'en due to a technicality in the process, that decision served as a significant precedent to confirm that land rights and title were not extinguished at the time of colonization. Similar to other nations, Aboriginal title to Wet'suwet'en traditional territory exists as a matter of law (their own law) and predates colonization. Therefore, the existence of the title does not depend on the British/Canadian legal system since the Indigenous sovereignty is affirmed at the same level as other European nations. Canadian courts can merely recognize Wet'suwet'en Aboriginal title, but they cannot create or modify it. The Wet'suwet'en and Gitxsan entered the treaty process negotiation with de federal and provincial governments in 1994 to have their territory formally recognized, establish measures for self-government, and find their own ways to leave the Indian Act behind. However, the process was suspended in 1995 because of the unrelenting insistency by the government to include land extinguishment and other colonizing clauses to advance with the discussions (Taiaiake, 2001).

The natural gas pipeline dispute exposed and exacerbated the internal tensions between the elected Chief and Council and the traditional forms of government represented by the Hereditary Chiefs. The Wet'suwet'en clan system is formed by five groups, each one of them represented by a number of Hereditary Chiefs: Tsayu (Beaver), Gilseyhu (Big Frog), Laksilyu (Small Frog), Gitdumden (Wolf/Bear), and Laksamshu (Fireweed/Owl). According to international and British legislation, at the time of colonization, Indigenous systems of property and ownership in their land were to be respected by the law of the European colonizing nation unless the Indigenous group was conquered or treaties were made with them. The British Crown never conquered or reached any kind of agreement with the Wet'suwet'en. Since the beginning of colonization, it did not manifest any intention to respect their traditional system of governance. As a matter of fact, beginning in the 186os, and guided by the controversial doctrine of discovery (as a colony) and later on by the Indian Act (as a province that just joined the Confederation), British Columbia began passing its own land laws and issuing property titles to European settlers in lands historically inhabited by Indigenous people without any legal right to do so. 
The Canadian courts have recognized these historical oversights in several instances where the justice system has acknowledged Indigenous rights to their traditional lands and livelihood practices ${ }^{2}$. While the court system can provide legitimacy, the nature of English common law has also been used to do the opposite and not be congruent with existing Indigenous legal concepts and legitimacies. In that sense, instead of recognizing the legitimacy of Indigenous title and institutions, the current provincial government continues to follow the policy of denial still associated with the doctrine of discovery. This explains in a great measure why the Crown has not been able to achieve satisfactory land claim agreements with the First Nations and the uncertainty about the province's legal authority over Indigenous lands until today.

\section{Mi'kmaq and the lobster fisheries}

On September 17, 2020, the Sipekne'katik First Nation, affirming their treaty rights to catch and sell fish, took the initiative to launch their own moderate livelihood system in Saulnierville and Middle West Pubnico Bay in western Nova Scotia. In commemoration of the $21^{\text {st }}$ anniversary of the 1999 Marshall landmark decision, this Mi'kmaq nation created a self-regulated fishery, distributing lobster licences and opening their fishing operations before the start of the official season on November 30. In the following days, non-Indigenous commercial fishers retaliated with acts of vandalism and violence and accusing the Mi'kmaq fishers of operating an illegal activity and threatening the capacity of the lobsters to replenish. Initially, non-Indigenous fishers removed Mi'kmaq lobster traps from the water and destroyed their equipment. A crowd of approximately 200 non-Indigenous individuals surrounded a lobster pound in Middle West Pubnico to protest. Mi'kmaq fishers have reported that protestors were barricading them inside and throwing rocks at the building. The group also threatened to burn the building with people inside and destroyed thousands of pounds of lobster. A few days later, on October 17, a suspicious fire burned to the ground the same lobster pound previously vandalized where Mi'kmaq caught lobster was being stored.

These events received widespread attention from national mainstream media that portrayed the tensions as a dispute between Mi'kmaq and non-Indigenous fisheries. However, many people failed to recognize that the Mi'kmaq rights to fish and develop a moderate livelihood in these waters have been granted to them since pre-contact times and reaffirmed in the 1999 Supreme Court Marshall decision. On October 21, the Sipekne'katik First Nation obtained a broad interim injunction prohibiting anyone from restricting the band members to access two wharves and a lobster pound in Nova Scotia.

A significant part of the problem derives from the fact that Mi'kmaq fishers, differently from nonIndigenous fishers, are allowed to fish from November to May, a period that is considered sensitive for the reproduction of the lobsters. In addition, it has not been defined by any regulatory agency or court the actual meaning of a "moderate livelihood." There are more than 5,70o registered non-Indigenous commercial fishers in Nova Scotia who allege that the Mi'kmaq are being used for large-scale commercial fishery corporations and are threatening the capacity of the lobsters to reproduce in a sustainable way. Because no one can explain the amount of money or a quota based on weight that could fit the criteria, the Mi'kmaq fishers were facing accusations for trying to honour their traditional ways of living. After waiting many years for the Federal government to confirm their fishing rights and without a clear system in place, the Mi'kmaq decided to be in charge of their self-regulated lobster operation.

2 Just to mention two relevant decisions, Calder (1973) and Sparrow (1990), became important references to influence other cases. 


\section{Discussion}

Donald Marshall, a Mi'kmaq fisher, was fishing for eel with his wife during the summer of 1993 in Pomquet Harbour, Nova Scotia. He was approached by the Department of Fisheries officers, who demanded a licence permitting fishing in the off-season. Marshall responded that his ancestors had fished in these waters of Nova Scotia for many generations, and the 1752 treaty covered him. Not agreeing with Marshall's version of the law, the police arrested him for fishing eels without a license during the off-season. Marshall's arrest marked the starting point of a six-year legal battle that resulted in a Supreme Court ruling stating that, based on treaty rights, Marshall could fish for a "moderate livelihood" at any time - he was thus acquitted of all charges. However, even though the court recognized Marshall's right to fish, the ruling did not provide any definition of a "moderate livelihood." The decision did not mention any amount or type of fish and did not provide guidance on whether the catch could be sold for subsistence purposes.

There was no doubt on the side of the Mi'kmaq fishers that the decision was a victory, but the language was open to interpretation. The court's legal terminology has been criticized as too general by both Mi'kmaq and non-Indigenous fishers. The ruling also defined that the Mi'kmaq do not have a right to "open-ended accumulation of wealth" but instead were restricted to trading for "necessaries" - a term not clearly specified that was borrowed from a 260-year-old treaty. Legal experts affirm the Marshall decision language was intended to bring the governments closer to the Mi'kmaq and non-Indigenous stakeholders to open discussions and find a long-term resolution. In fact, the Supreme Court of Canada acknowledged the protection of these rights under section 35 of the Constitution Act, 1982. However, since that time, and as it has happened on several occasions with other Indigenous nations, the Crown has been hesitant to involve the Mi'kmaq in meaningful negotiations.

The central causes of the present conflict are associated with basic misinterpretations by many people not fully aware of the nature of Mi'kmaq's inherent and constitutionally protected fishing rights and the Crown's failure to acknowledge these rights. More than 250 years before Marshall was arrested for catching eels, Mi'kmaq nation leaders had begun signing treaties with colonial authorities in Nova Scotia. Today, these treaties are described as "Peace and Friendship Treaties" because they laid the foundation upon which the Mi'kmaq and other Indigenous nations accepted to live peacefully with the British. The first treaty was signed in 1726. In 1752, a new peace treaty was signed confirming previous peace treaties, declaring the end of hostilities, and suggesting some directions for implementing Indigenous trading rights. The Mi'kmaq's rights to catch and sell fish are not only linked with practices from their ancestors before colonization but are also protected under the Constitution of 1982.

If we expect the legal system to pursue recognition for Indigenous rights, the Canadian mentality needs to recognize it in the first place. Wayne Warry summarized: “...Canadians have been unable to come to grips with Aboriginal issues and why we have created a country not fully inclusive of Aboriginal peoples" (Warry, 2007: 13). Doug Harris suggests that laws surrounding natural resource development have been used as another instrument to enact colonial authority and interests. Furthermore, the establishment of a regulated Indigenous fishery in British Columbia in a similar way as it is happening in Nova Scotia "was the device with which the state constructed a 'traditional economy,' marginalizing native control and, at the same time, integrating Native peoples into the global economy as subsidized labour" (Harris 2001: 203). North America's natural resource industry, guided by bureaucratic administrative and legal wrangling, has been actively displacing Indigenous communities and negatively affecting their livelihoods from coast to coast in the name of economic development. (Macklem, 2002; Nadasdy, 2003).

This decision from the Sipekne'katik fishers to launch their self-regulated fishing operations does not qualify as an illegal activity as alleged by the non-Indigenous fishers. On the contrary, they have waited for 21 years for the Crown to demonstrate genuine intentions to act upon the Marshall decision and invite the Mi'kmaq communities to debate and reach a definition of "moderate livelihood" that would satisfy all the 
players involved. Traditional ecological knowledge that many indigenous nations possess has often been disregarded, and priority has been given to Western knowledge, or interpretation, of the land (Macklem, 2002; Nadasdy, 2003). After prolonged and repeated failures of the Crown to recognize and implement Mi'kmaq's commercial fishing rights, they decided to take a stand and honour the ways of their ancestors. Fisheries experts from DFO (Department of Fisheries and Oceans) and Dalhousie University affirm that considering the small impact caused by livelihood fishery, no danger is posed to the lobster stocks in the region, which negates any concerns about the potential adverse effects on the conservation of the lobster stock. The motivation to invoke sustainability as an argument is clearly associated with the effort to limit the Mi'kmaq from exercising their rights confirmed by the Supreme Court and protected by the Constitution.

\section{Pikangikum and the Turtle case}

Sherry Turtle, Audrey Turtle, Loretta Turtle, Cherilee Turtle, Rocelyn R Moose and Tracey Strang are all members of the Pikangikum First Nation, and each of them live, together with their children, on the reserve territory in northern Ontario. The six women pled guilty to drinking and driving offences that generated mandatory jail sentences of not more than 90 days. According to the Criminal Code, the women could make the request to serve these sentences out on weekends through what is called intermittent sentencing. The obstacle, in this case, is that the Pikangikum First Nation Territory is an isolated fly-in community located more than 300 hundred kilometres from the nearest district jail in the city of Kenora. Additionally, it is financially and logistically impossible for them to travel to and from there, from weekend to weekend, paying their own expenses, to serve out their sentences.

Faced with this challenge, each woman decided to bring their applications to the court system. They claimed that their incapacity to comply with the requirements of an intermittent sentence due to lack of accessibility violated their rights to equal protection under the law. They further argued that abandoning their families and travelling great distances every weekend constitutes cruel and unusual punishment and abuse of the court's process. Ultimately, the women required a constitutional exemption from having to abide by the sentence on these conditions.

On October 2, 2020, Justice David Gibson ruled that the women's rights to equality were violated because they could not access intermittent sentences in their fly-in First Nation to serve their impaired driving sentences of 90 days or less. Gibson also concluded in his decision that "in a community where 75 percent of the population is under the age of 25 , removing mothers from their children for extended periods of time will undoubtedly exacerbate existing problems in this vulnerable and destabilized First Nation." (...) In this case, the issue is not over-incarceration [of Indigenous people], per se, but rather the direct extension of the corrosive effects of colonization." Gibson noted the crowded Kenora District Jail, built in 1926, comprised primarily Indigenous inmates living in inhumane conditions. The women and their families would therefore benefit from serving intermittent sentences.

For thousands of years, Pikangikum and other Indigenous nations had been able to thrive using their traditional systems of justice and internal mechanisms of punishment that predate contact with European settlers. The judge also took into consideration the harmful impacts that the integration into Canadian Confederation has brought to Pikangikum's autonomy and cultural system. With almost two decades of experience ruling cases from Pikangikum and other First Nations in similar conditions, the judge struggled to reach a sentence that might be appropriate considering the history of drinking and substance abuse of the community. The Court declined to offer the applicants the constitutional exemption as requested because 
the Crown had undertaken the responsibility to transport, at its expense, all the applicants back and forth to the jail until their sentences were served. Justice Gibson, however, encouraged the Crown to consult with Pikangikum leadership about the justice system in their community.

\section{Discussion}

The fundamental point of reflection of this case is how particular Criminal Code provisions of general application can be extended to Pikangikum First Nation residents in terms of them being equal under the law and whether it entails some kind of unconstitutional impact. Section 35(2) of the Constitution Act, 1982 recognizes that First Nations, like Pikangikum, lived in distinctive societies, that their members are described as "peoples" who have been recognized by the Supreme Court as holders of community-based rights by virtue of their connection to their land. Additionally, the same section strongly suggests that the defendants, as on-reserve members of the Pikangikum First Nation, belong to a group enumerated in section 15 of the Charter, namely, a nation. As a signatory of Treaty 5, this community has also recognized in the Constitution the right to be consulted in their traditional and cultural forms to regulate their internal affairs, such as crime and punishment.

The court heard extensive evidence on the "total disruption" caused by colonization and the subsequent growth in crime in Pikangikum - much of it associated with devastating substance abuse effects. As stated during the court hearings, one of the accused women has lost three siblings to suicide. R. $v$. Turtle is an appropriate reminder of the damage that results when Indigenous peoples are forced to rely on legal regimes grounded in inherently discriminatory practices that have no understanding or respect for Indigenous realities.

According to Indigenous rights specialists, concerns about the application of Canada's criminal justice system to Indigenous peoples extend beyond the particular provision of the Criminal Code at issue in this case. Being deprived of the opportunity to serve a jail sentence intermittently because of their status as on-reserve band members of the Pikangikum First Nation constitutes the deprivation of a legal benefit. It also creates a distinction in law between themselves and other members of the Canadian society. In other parts of the country, Indigenous groups decided to exercise their inherent jurisdiction and develop their own strategies to take control of their legal systems rather than waiting for the government to show a genuine disposition to reform the current system. The significance of these initiatives and the impact of Turtle decision cannot be overstated. The issues at stake here are not about returning particular administrative decisions to Indigenous governments. This is about decolonizing the justice system by providing opportunities for Indigenous peoples to reclaim the legal processes that historically served their communities.

Bell \& Asch (2002: 45) reveal that Aboriginal judicial autonomy is highly unlikely should the courts continue to utilize Canadian law on Aboriginal traditions in terms of precedent in cases. In terms of precedent, Bell and Asch's writing effectively argue about the disconnect in Aboriginal and Canadian conceptions of precedent and why examples in Canadian law are ineffective for Aboriginal cases. Judge Gibson's decision echoes LaRocque's argument, noting that oversimplifying Aboriginal culture results in "infantilizing the very cultures Aboriginal peoples are trying to build up in the eyes of the colonizers" (2002: 77).

In sum, as stated by judge Gibson, Ontario Courts sentencing ignores treaty obligations and violates the Charter equality rights of six Pikangikum women by forcing them to fly south, at their own expense, every weekend to serve out their mandatory minimum jail sentences. Over time, the disruption to Pikangikum's traditional way of life because of the Crown's colonial and discriminatory policies produced high rates of substance abuse, criminality and suicide within the community. Despite this, the imposition of foreign laws on Indigenous peoples without any recognition or regard for the existence of their own legal systems is another example of the inadequate Crown-Indigenous relations in Canada. 


\section{Conclusion}

The uniqueness of each of these three cases illustrates the need for an individualized approach, which respects the particular history of each community and their relationship with colonial authorities and processes. However, the unifying element that connects them and many others around Canada is the direct action taken by the members of these communities to honour frequently neglected nation-to-nation agreements instead of waiting for the Crown to take this step. Attitudes such as the blockades established by the Wet'suwet'en, the self-regulated fishery organized by the Mi'kmaq, and the Turtle decision represent an active stand that not only passes through the court system but is pointing to more prominent elements of the relationship between the Crown and Indigenous nations in Canada. These actions cannot be merely understood as civil disobedience or illegal activities. They are challenging legal regimes that have consistently failed Indigenous peoples and have worked to reconstruct them in accordance with settler legislations and priorities.

Simpson (2017: 25) explores the familiarity of Indigenous peoples with the concept of reconciliation and encourages that the concept is not imposed upon Indigenous cultures by Canadian institutions but instead should be determined by Indigenous peoples and what they deem to be beneficial. Reconciliation may be able to emerge from the philosophy of balance and restoration and rise above the necessity of losers and winners as commonly postulated by the Canadian systems (Johnson, 2007: 44-46). John Borrows defends the significance of Indigenous legal traditions as a third source of law in Canada, equal to that of common law and civil law. He emphasizes that the present bi-juridical system negatively reflects Canada's legal foundations resulting in an unstable constitutional structure that "risks harming all who depend upon it for security and protection" (2010: 15). Canadian law has characterized the Indigenous title as a form of property right, which is portrayed as a burden on the underlying crown title (Asch \& Zlotkin, 2002: 212). Instead of recognizing the existence of Indigenous title, the current government adheres to a policy of denial (Gunn \& McIvor, 2020). Contrary to the federal government's understanding that the Canadian state holds the underlying title, Indigenous people believe that their title is awarded to them by the Creator and is dependent on their interconnection with the land (Asch \& Zlotkin, 2002: 215).

The court system is not solely an instrument dedicated to provide order and legitimize the rule of law. With its postulation of equality, the law could effectively transcend the material interests of the colonial settlers while simultaneously creating the possibility of justice for Indigenous people (Harris, 2001). For the courts to be used as a beneficial path to recognizing Indigenous rights, new models must be constructed that accommodate true, multidimensional lives (LaRocque, 2002). The examples of legal resurgence in British Columbia, Nova Scotia, and northern Ontario utilize Indigenous traditions in a contemporary context to bring meaning to a greater diversity of populations around the country.

Some may view that the current judicial system may be disturbed with the upheaval of precedents to suit a fair representation of Indigenous needs. However, Indigenous judicial systems existed before colonialism and could be debated to have greater significance due to their historical connections. Thus, the modification of Canadian systems needs to be addressed to suit Indigenous cultures and prevent cultural degradation and support fair judicial trials. Incorporating Indigenous judicial systems into the existing Canadian government may lead to the Indigenous societies more appropriately defining themselves and their cultural practices within the confines of the current judicial system.

If reconciliation is to be achieved in a meaningful way, self-determination is a crucial aspect of reclaiming Indigenous identity from the Canadian government, which has used legislation like the Indian Act to quantify Indigeneity as finite. Therefore, court systems have become more accessible for Indigenous individuals to participate. However, these systems remain imperfect as they continue to incorporate ideas of culture that are incorrect or unrepresentative of actual Indigenous distinctiveness. 
Ultimately, improvements in Indigenous rights in Canadian systems may only occur with further participation from Indigenous communities' representatives and the education of the general public. When we continue to hold to jurisprudence as the only source that informs the evolution of Indigenous rights framework, then we are also affirming Settler-societies theoretical and philosophical legal frameworks. These systems must work in a complementary fashion if we are to move toward Indigenous and Non-Indigenous unity.

Received: December 27, 2020

Approved: September 09, 2021

\section{Bibliographical References}

ASCH, Michael; ZLOTKIN, Norman. 2002. "Affirming Aboriginal Title: A New Basis for Comprehensive Claims Negotiations." In: Michael Asch (ed.), Aboriginal and Treaty Rights in Canada. Vancouver: UBC Press. pp. 208-230.

BELL, Catherine; ASCH, Michael. 2002. "Challenging Assumptions: The Impact of Precedent in Aboriginal Rights Litigation.” In: Michael Asch (ed.), Aboriginal and Treaty Rights in Canada. Vancouver: UBC Press. pp. 38-74.

BORROWS, John. 2010. Canada's Indigenous Constitution. Toronto: University of Toronto Press.

GUNN, Kate; MCIVOR, Bruce. 2020. “The Wet'suwet'en Aboriginal Title and Rule of Law: An Explainer.” First Peoples Law (14 December 2020), online: 〈https:||www.firstpeopleslaw.com/public-education/blog/ the-wetsuweten-aboriginal-title-and-the-rule-of-law-an-explainer>.

HARRIS, Douglas. 2001. Fish, law and colonialism: the legal capture of Salmon in British Columbia. Toronto: University of Toronto Press.

JOHNSON, Harold. 2007. Two families: treaties and government. Saskatoon: Purich Pub.

LAROCQUE, Emma. 2002. "Re-examining Culturally Appropriate Models in Criminal Justice Applications." In: Michael Asch (ed.), Aboriginal and Treaty Rights in Canada.Vancouver: UBC Press. pp. 75-96.

MACKLEM, Patrick. 2002. "The Impact of Treaty 9 on Natural Resource Development in Northern Ontario". In: Michael Asch (ed.), Aboriginal and Treaty Rights in Canada.Vancouver: UBC Press. pp. 97-134.

NADASDY, Paul. 2003. Hunters and Bureaucrats: Power, Knowledge and Aboriginal-State Relations in the Southwest Yukon. Vancouver \& Toronto: UBC Press.

SIMPSON, Leanne B. 2017. Dancing on Our Turtle's Back (Chapters 1 \& 2). Winnipeg: Arp Books.

TAIAIAKE, Alfred. 2001. "Deconstructing the British Columbia Treaty Process". Balayi: Culture, Law and Colonialism, 3: 37-65.

WARRY, Wayne. 2007. Ending Denial: Understanding Aboriginal Issues. Toronto: Broadview Press.

\section{Frederico Oliveira}

https://orcid.org/0000-0003-2916-284X

Mailing address: 28 Empress Ave, Suite 912. Toronto, ON.Canada. M2N 6Z7

Email: foliveira@lakeheadu.ca 